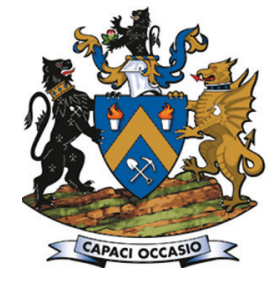

Affiliation:

${ }^{1}$ School of Geosciences,

University of the Witwatersrand, South Africa

${ }_{2}$ Anglo American Technical

Solutions, South Africa

Correspondence to:

K.L. Youlton

Email:

kyoulton@ymail.com

Dates:

Received: 2 Jul. 2019

Revised: 29 Mar. 2021

Accepted: 21 Apr. 2021

Published: June 2021

\section{How to cite:}

Youlton, K.L,. Kinnaird, J.A., and

Youlton, B.J. 2021

Depositional environment -

The original control on gold processing.

Journal of the Southern African Institute of Mining and Metallurgy, vol. 121 , no. 6 , pp. 267-276.

DOI ID:

http://dx.doi.org/10.17159/2411-

9717/811/2021

ORCID

K.L. Youlton

https://orchid.org/0000-0001-

7833-4471

J.A. Kinnaird

https://orchid.org/0000-0001-

5879-8324

\title{
Depositional environment - The original control on gold processing
}

\author{
K.L. Youlton ${ }^{1}$, J.A. Kinnaird ${ }^{1}$, and B.J. Youlton ${ }^{1,2}$
}

\section{Synopsis}

Methods for treating and processing refractory gold ores are well established. However, what is less well understood is how the formation of the gold-bearing deposits affects gold processing and extraction. In order to evaluate the effect of ore genesis on gold extraction a number of South African gold deposits were studied. These included complex Pilgrim's Rest samples as well as refractory Fairview, Barbrook, and Consolidated Murchison samples. We found the refractory nature of gold ores is controlled by a limited number of well-understood mineralogical factors. Solid solution gold is linked to low temperature and pressure conditions in fine-grained sedimentary lithologies, while reactive pyrrhotite can form from hydrothermal fluids associated with mafic magmatic rocks. These formational controls can be used to identify and avoid complex deposits at a desktop study phase, or address and reduce complications further along the pipeline using early mineralogical studies.

\section{Keywords}

gold processing, refractory gold, ore mineralogy.

\section{Introduction}

Gold has been an important commodity throughout much of human history, and is thought to be one of the earliest metals mined (Kongolo and Mwema, 1998; Reardon, 2011). Early gold recovery from stream bed sediments involved manual or gravity-based separation methods; beyond this, little advancement took place until underground mining was initiated in Russia in 1744, where crushing, gravity concentration, and amalgamation were used for gold extraction (Bath and Duncan, 1973; Kongolo and Mwema, 1998; Burt 1999). By 1848, a process to extract gold using chlorine gas was developed and extensively used, but was limited in its capacity to process ore of low grade (Eidem, 1974). Thus, when cyanidation was first patented in 1888, it was rapidly commercialized, first in New Zealand (in 1889) and subsequently in a number of countries including South Africa, the USA, Mexico, and France (Stanley, 1987; Reardon, 2011). The advent of the cyanide process is credited with reviving the failing Witwatersrand gold mining industry in 1890 when the mined ore transitioned from oxidized to sulphidic, with associated copper, lead, iron, and zinc sulphides which prevented effective recovery using amalgamation, the method used on the Witwatersrand prior to cyanidation (Fivaz, 1988).

In recent years there has been a dearth of new gold discoveries. Global gold exploration investment from 2007 to 2016 amounted to US\$65 billion, while the value of gold deposits discoveries in this same period was less than half of this amount (McKeith et al., 2010; Schodde, 2016). Furthermore, in the past 15 years, only an extremely limited number of the discoveries that have been made could be considered world-class (greater than 15 million ounces) (Holmes, 2017). This declining state has forced the gold industry to rely on alternative methods for ensuring sufficient resources and reserves are owned in order to remain competitive and relevant.

Cyanidation is extremely effective at processing more readily extractable/free-milling gold. However, with the diminishing number of orebodies that are both easily accessible and amenable to cyanidation, increasing attention has been given to the discovery and exploitation of refractory ores (Fraser, Walton, and Wells, 1991; Chryssoulis, Cabri, and Salter, 1987; Hasab, Rashchi, and Raygan, 2014; Vaughan and Kyin, 2004).

Gold deposits occur in a number of different geological settings, only a few of which are host to refractory gold ores. A knowledge of the link between the geological setting of a gold deposit and potential processing problems could be an important factor in the early stages of deposit targeting, an increasingly important phase of exploration. Should it be possible to target geological areas with a higher chance of hosting simple ores, particularly with free-milling gold, it would certainly be 


\section{Depositional environment - The original control on gold processing}

worth factoring this information into early desktop studies. Additionally, understanding the formation and mineralogy and therefore the metallurgical nature of the deposit early in a project will prevent later complications, or at least provide an understanding of the issues likely to arise and act as an early warning of future metallurgical complications.

The present study involved an investigation of selected South African refractory/complex gold deposits, their geological settings, mineralogy, and conditions of metallogenesis, to gain a better understanding of the formation of the complex ores and the causes of processing problems.

\section{Extractive metallurgy}

Gold, a noble metal, is by definition resistant to chemical action, therefore there are a limited number of solvents capable of dissolving it (Moffa, 1977). Effective gold dissolution systems typically require an oxidant capable of oxidizing the gold, as well as a reactant/complexing agent able to form a reasonably stable gold complex post-oxidation (Kongolo and Mwema, 1998; Marsden and House, 2006).

Cyanide has been used in the extraction of gold for over 100 years and the chemistry of its interaction with gold is well understood. Sodium (or potassium) cyanide solution is added to the ground ore in order to dissolve gold. The overall reaction proceeds according to Equation [1] (Kongolo and Mwema, 1998; Marsden and House, 2006):

$$
4 \mathrm{Au}+8 \mathrm{NaCN}+\mathrm{O}_{2}+2 \mathrm{H}_{2} \mathrm{O} \rightarrow 4 \mathrm{AuNa}(\mathrm{CN})_{2}+4 \mathrm{NaOH}
$$

Oxygen acts as an oxidizing agent, while $\mathrm{CN}^{-}$dissociates from sodium and complexes with the gold (Habashi, 1967; McNulty, 1989). Cyanide-gold complexes are significantly more stable than those yielded by alternative lixiviants, making cyanide a useful tool in gold extraction (Chen et al., 1980; Aylmore, 2005, 2016a). This reaction is maintained at a basic $\mathrm{pH}$ of approximately 10-11, as this lowers the reduction potential and is the most efficient leaching condition for many ores (Kongolo and Mwema, 1998). Furthermore, at more acidic conditions HCN is evolved, posing a safety concern as well as an economic one due to increased reagent losses (Eisler and Wiemeyer, 2004).

\section{Refractory ores}

The cyanidation reaction typically proceeds quite readily, which accounts for its widespread use. However, its effectiveness is limited in the presence of certain interfering agents. The nature of these agents allows for the classification of gold ores, and while the classification system may vary from author to author (Chryssoulis and McMullen, 2005; Chryssoulis, Cabri, and Salter, 1987; Haque, 1987; Karimi et al., 2010; Komnitsas and Pooley, 1989; Miller, Wan, and Diaz, 2005; Monhemius, 1987; Vaughan, 2004; Zhou and Cabri, 2004) the overall concept is the same. The following description has been strongly based on Vaughan, (2004). Three distinct gold types exist in this system (Figure 1); free milling, complex, and refractory (in increasing order of processing difficulty).

Free milling ores encompass all ores that readily yield their gold by cyanidation, with no factors that complicate or reduce extraction efficiency. A gold recovery of $90 \%$ or more defines free milling ores (La Brooy, Linge, and Walker, 1994; Marsden and House, 2006).

Complex ores refers to ores from which high gold recoveries are possible, but only under modified or more intense leaching conditions. Complex ores can be subdivided into two categories: preg-robbing and reactive. Preg-robbing ores contain material capable of absorbing gold-cyanide complexes during leaching. This material tends to be carbonaceous matter (specifically elemental and organic carbon), although clays are also thought to have a minor capacity for preg-robbing (Goodall, Leatham, and Scales, 2005; Miller, Wan, and Diaz, 2005; Vaughan, 2004). The effects of preg-robbing can be countered (to a limited degree) in a number of ways: (1) addition of kerosene to deactivate the carbonaceous material, (2) carbon-in-leach, where activated carbon is present throughout the leach and can absorb the gold onto its surface more rapidly than the competing preg-robbing component (La Brooy, Linge, and Walker, 1994; Vaughan, 2004). Reactive ore refers to any ore that contains material that reacts with reagents required for successful gold leaching. These reactive materials tend to be cyanicides (i.e. they react with and reduce the available concentration of cyanide) or oxygen consumers. Examples of these minerals include; pyrrhotite, copper minerals (with the exception of chalcopyrite) such as chalcocite, malachite, azurite, and cuprite, as well as most base metal minerals that contain iron, arsenic, antimony, zinc, nickel, and cobalt (Aylmore and Muir, 2001; Karimi et al., 2010). These ores can be dealt with by adding higher concentrations of reagents than would be required for standard cyanidation.

Refractory ores refers to deposits from which acceptable gold recoveries cannot be achieved using standard procedures. There are two types of refractory ores, those with physically and chemically locked gold, both of which make the gold inaccessible to lixiviants. Physically locked gold occurs when gold is present as very fine inclusions, typically within a sulphide mineral. Chemically locked gold can be found in discrete gold minerals such as gold tellurides, aurostibite, aurocupride, and maldonite (Harris, 1990; Vaughan, 2004). Chemically locked gold can also refer to gold present as solid solution within certain minerals; this means that atomic gold is present within crystal lattices (Chryssoulis, Cabri, and Salter, 1987; Haque, 1987; Komnitsas and Pooley, 1989; Monhemius, 1987; Vaughan and Kyin, 2004). Arsenopyrite, and to a lesser extent pyrite, may host solid solution gold (Barker et al., 2009; Vaughan, 2004; Vaughan and Kyin, 2004).

In order to ensure acceptable recoveries from refractory ores, it is usually necessary to implement a pre-treatment step in the extraction process. Examples of pre-treatments include ultrafine milling, pressure oxidation, biological oxidation (BIOX) and in older designs, roasting. Pressure cyanidation, while not a pre-treatment, can also be an effective option (Davis, 1986; Haque, 1987; Lindström, Gunneriusson, and Tuovinen, 1992; Monhemius, 1987).

\section{Gold deposits}

There are a number of important gold deposits in South Africa, accounting for significant gold production in the past and into the present (Janisch, 1986). The Witwatersrand Basin is host to the largest gold deposit in the world, accounting for nearly a third of the world's total gold production (Frimmel, 2005). This deposit will not be discussed further as it is a predominantly free-milling ore and the focus of this study is on refractory type deposits. While refractory deposits in South Africa are relatively small compared to the Witwatersrand Basin, they are still important. The deposits studied were the Fairview and Barbrook mines in the Barberton area, Pilgrim's Rest, and Consolidated Murchison.

\section{Barberton, Fairview, and Barbrook}

The Barberton greenstone belt is one of the oldest and best 


\section{Depositional environment - The original control on gold processing}

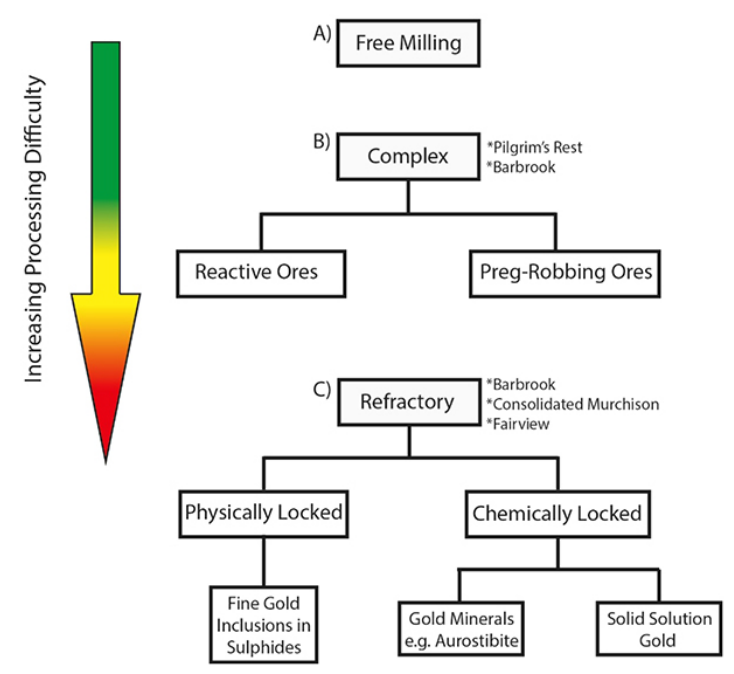

Figure 1-A diagram outlining the three main types of gold deposit: (1) free milling, (2) complex, and (3) refractory. The studied deposits have been grouped with their respective deposit types

preserved supracrustal sequences in the world. The belt occurs near the town of Barberton, Mpumalanga Province, approximately $280 \mathrm{~km}$ east of Johannesburg. The mechanism of mineralization is a contentious issue among researchers of this gold district. In the past there was consensus that the mineralization at Barberton had an orogenic genesis, linked to the accretion of the greenstone belt (de Ronde, de Wit, and Spoomer, 1994; Goldfarb, Groves, and Gardoll, 2001; Groves et al., 1998). However, a number of more recent papers suggest that the mineralization occurred later than the accretion, and was likely to have been associated with a subsequent extensional event (Dirks, Charlesworth, and Munyai, 2009; Dirks et al., 2013; Munyai, Dirks, and Charlesworth, 2011). Isotope studies suggest that the mineralizing fluids originated from external sources that were probably dominantly magmatic, and migrated upwards through brittle-ductile shear zones, fractures, and faults (de Ronde, de Wit, and Spooner, 1994; Munyai Dirks, and Charlesworth, 2011; Ward, 1999).

\section{Consolidated Murchison}

Consolidated Murchison represents an important antimonygold deposit within the Murchison greenstone belt, an Archean volcano-sedimentary belt. The deposit is located in the northern Kaapvaal Craton, near Gravelotte, $50 \mathrm{~km}$ west of Phalaborwa and $370 \mathrm{~km}$ northeast of Johannesburg (Anhaeusser, 2001; Davis, 1986). There has been uncertainty regarding the metallogenesis of the Antimony Line, which is host to the mineralization. Models for both syngenetic and epigenetic origins have been proposed. However the complex deformation that has occurred makes accurate studies of this region extremely difficult. The ores appear to be orogenic despite being associated with significant metamorphic remobilization. The simultaneous occurrence of both gold and antimony in their various forms suggests that a single process was responsible for this enrichment (Jaguin et al., 2012; Pearton, 1982).

\section{Pilgrim's Rest}

The Sabie-Pilgrim's Rest gold district is located in Mpumalanga, west of the Drakensberg, approximately $320 \mathrm{~km}$ east-northeast of Johannesburg. The Sabie-Pilgrims Rest orebodies are epithermal deposits, hosted by the Proterozoic Transvaal Supergroup
(Boer et al., 1995). The mineralization is thought to have been contemporaneous with the formation of the Bushveld Complex. The emplacement of such a large volume of magma (450 000 $\mathrm{km}^{3}$ (Cawthorn and Walraven, 1998; Finn et al., 2015) is likely to have initiated the thrust system that was exploited by the hydrothermal mineralizing fluids that emanated from the intrusion to form this epithermal gold deposit. Isotopic data, fluid inclusion studies, and elemental fingerprints all support the Bushveld Complex as the origin of the fluids (Boer et al., 1995; Meyer and Robb, 1996; Tyler, 1986; Tyler and Tyler, 1996).

As such, the aim of this study is to use the characterization of the refractory ores and their depositional environments to determine the conditions of formation of the refractory deposits in order to apply this information on a larger scale to exploration and remote targeting.

\section{Methods and materials}

The samples used for this study were obtained from the direct feed to the respective processing plants. The sampling took place after coarse crushing but before any other processing was employed. Attempts were made to ensure that the mineralogy was representative of the typical run-of mine feed from the deposit, as determined by the on-site geologists. The ores were characterized using a combination of chemical assay, optical microscopy, X-ray diffraction (XRD), and Mineral Liberation Analyser (MLA).

\section{Optical microscopy}

As the samples were composites of run-of-mine ore, it was necessary to prepare several thin sections to ensure that the petrological studies were completed on the full range of lithologies. An average of 10 sections from each deposit were prepared directly from the ore, in order to obtain an accurate representation of the respective deposits. The sample surfaces were selected to be as representative as possible, while still including important mineralization features.

\section{Chemical assay}

Gold assays were performed using fire assay and atomic absorption spectroscopy (AAS). X-ray fluorescence (XRF), inductively coupled plasma-mass spectrometry (ICP-MS), and inductively coupled plasma-atomic emission spectroscopy (ICP-AES) were utilized to supplement mineralogical data. XRF provided information regarding the major elements $\left(\mathrm{SiO} 2, \mathrm{Al}_{2} \mathrm{O}_{3}\right)$, while ICP-MS/AES was used for trace elements $(\mathrm{Cu}, \mathrm{Ni}, \mathrm{Pb}, \mathrm{Zn}$, $\mathrm{Sb}$, etc.).

\section{$X R D$}

The samples were pulverized to ensure the best possible results. Analyses were done using a $\mathrm{Co}-\mathrm{K} \alpha$ radiation source and a Panalytical X'pert Pro diffractometer.

\section{Automated scanning electron microscopy}

Automated scanning electron microscopy using a MLA (Mineral Liberation Analyser) was performed on comminuted material. The typical grind size recommended for gold leaching is $80 \%$ passing $75 \mu \mathrm{m}$ (Marsden and House, 2006), and therefore the sample characterization, particularly the gold, was performed at this grind. The gold grains were mapped using XBSE measurement mode. The MLA instrument was a FEI XL40 ESEM with two EDAX Sapphire Si(Li) EDS detectors. The MLA identification was performed using spectra matching, as is typical for MLA. 


\section{Depositional environment - The original control on gold processing}

Several terms are used to describe the data from MLA analyses. The grain sizes are presented in equivalent circular diameter (ECD). Mineral association represents the percentage of the surface area of a certain mineral that is bordered by another. Liberation is the area of the mineral of interest relative to the area of the total host particle, while mineral exposure can be described as the percentage of the grain that has a free, exposed surface.

The number of identified gold grains that were characterized varies with each sample, and therefore the reliability of this characterization may vary. For example, the Barbrook and Consolidated Murchison samples contained slightly fewer than the ideal number of gold grains and therefore the conclusions may be less reliable than those for the Pilgrim's Rest, and Fairview samples.

\section{Results - deposit mineralogy}

\section{Fairview, Barberton}

The mineralization at Barberton is hosted by a highly altered lithology comprising lithic quartz fragments, with a notable alignment, within a finer-grained matrix of chlorite, dolomite, magnesite, and to a lesser extent muscovite. Ore minerals are present either in veins/fractures, where the grains tend to be large and euhedral, or as disseminations throughout the whole rock, where they tend to be fine and sub- to anhedral. These minerals include pyrite, arsenopyrite, and minor visible gold (Figure 2A). Gold grades in the studied material are close to $12.5 \mathrm{~g} / \mathrm{t}$ (Table I) and this high grade is reflected in the gold particle count (Table II). At a grind of $80 \%-75 \mu \mathrm{m}$, visible native gold was $99.7 \%$ liberated, with a surface exposure/leach reactivity of $99.7 \%$. Gold grains range in size from $0.5 \mu \mathrm{m}$ to 425 $\mu \mathrm{m}$ (Figure 3A), with the most significant contribution to the total gold weight percentage in the range of $180 \mu \mathrm{m}$ to $425 \mu \mathrm{m}$. The large range in grain size, as well as the presence of coarse gold, will affect the leach time. Minerals commonly associated with the gold include pyrite (3.8\%), arsenopyrite (3.3\%), and quartz $(0.9 \%)$ (Figure $2 \mathrm{~B})$. The discrepancy between the visible gold content and the high grade $(12.5 \mathrm{~g} / \mathrm{t} \mathrm{Au})$ suggests that there is gold that is invisible to both optical petrology and MLA. Based on previous characterizations of the ore, this is likely to be due to solid solution gold present within arsenopyrite (Anhaeusser, 2001, 2015).
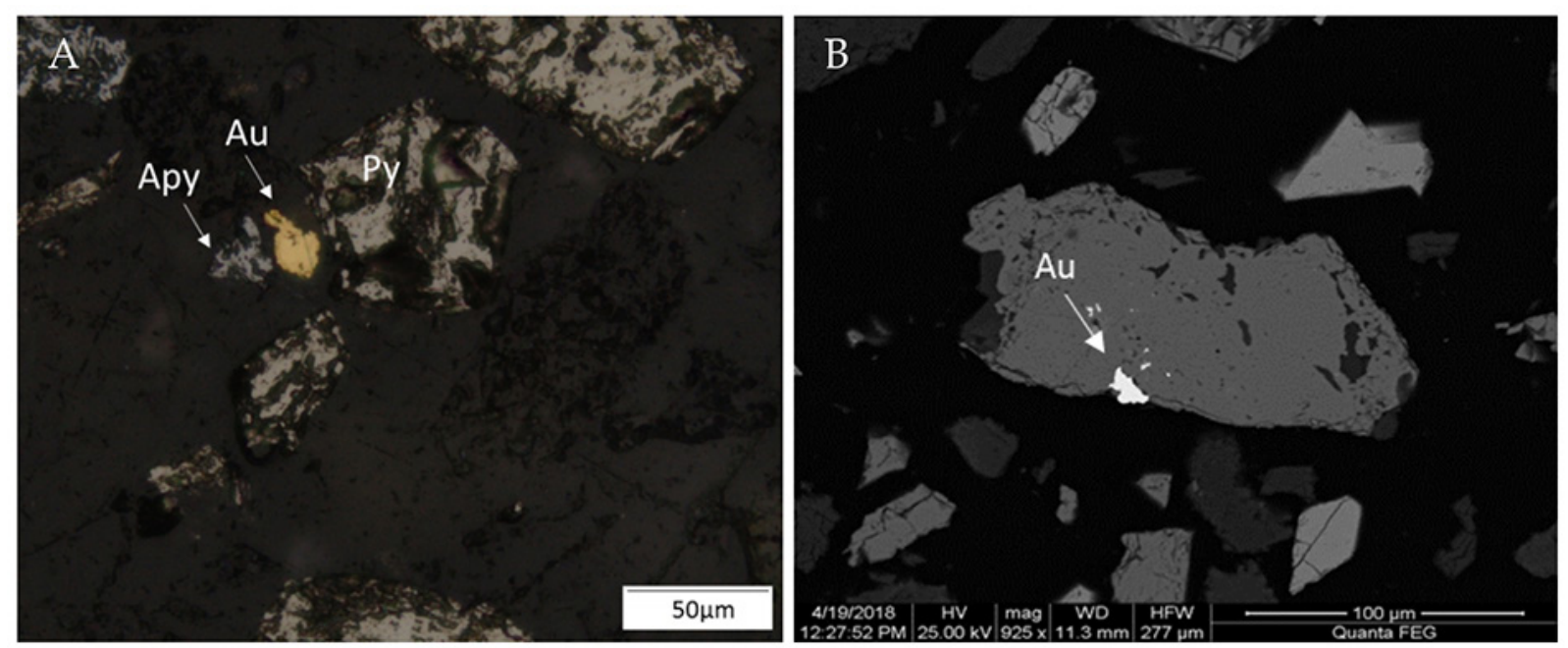

Figure 2-Typical mineralization found at Fairview. (A) Reflected light image of ores including arsenopyrite (Apy), pyrite (Py), and gold (Au). The gold grain has an equivalent circular diameter (ECD) of $46.5 \mu \mathrm{m}$. (B) BSE image of gold included within pyrite, resulting in limited liberation, moderate exposure, and an ECD of $10.7 \mu \mathrm{m}$

Table I

Chemical assay data, including gold grades and potentially deleterious elements

\begin{tabular}{|c|c|c|c|c|c|c|c|c|c|c|c|c|}
\hline Sample & $A u(g / t)$ & S (\%) & C (\%) & Org. C (\%) & As (\%) & Cu (ppm) & $\mathrm{Fe}(\%)$ & Co (ppm) & $\mathrm{Ni}(p p m)$ & $\mathrm{Sb}(p p m)$ & Zn (ppm) & $\mathrm{Pb}$ (ppm) \\
\hline Fairview & 12.5 & 2.86 & 1.27 & & 0.81 & 84 & & 50 & 491 & & 124 & $<20$ \\
\hline Barbrook & 2.08 & 8.06 & 3.94 & 0.23 & 0.23 & 597 & 15.3 & - & 472 & 65 & 2330 & 579 \\
\hline Consolidated Murchison & 3.04 & 6.29 & 3.55 & 0.13 & 2.96 & 164 & 10.2 & - & 700 & 70100 & 98 & 87 \\
\hline Pilgrim's Rest & 29.4 & 29.6 & 0.7 & 0.14 & 0.35 & 7230 & 25.5 & - & 84 & 931 & 47 & 108 \\
\hline
\end{tabular}

Table II

Grain and particle count used to characterize the samples

\begin{tabular}{|c|c|c|c|c|c|c|c|}
\hline \multirow[t]{2}{*}{ Sample } & \multicolumn{3}{|c|}{ Native gold } & \multicolumn{4}{|c|}{ Aurostibite } \\
\hline & Particles & Grains & $\mathrm{Au}(\%)$ & Particles & Grains & $\mathrm{Au}(\%)$ & Total gold-bearing grains \\
\hline Fairview & 224 & 321 & 100 & - & - & - & 321 \\
\hline Barbrook & 47 & 50 & 100 & - & - & - & 50 \\
\hline Consolidated Murchison & 22 & 23 & 37.2 & 44 & 44 & 62.8 & 67 \\
\hline Pilgrim's Rest & 156 & 169 & 100 & - & - & - & 169 \\
\hline
\end{tabular}




\section{Depositional environment - The original control on gold processing}
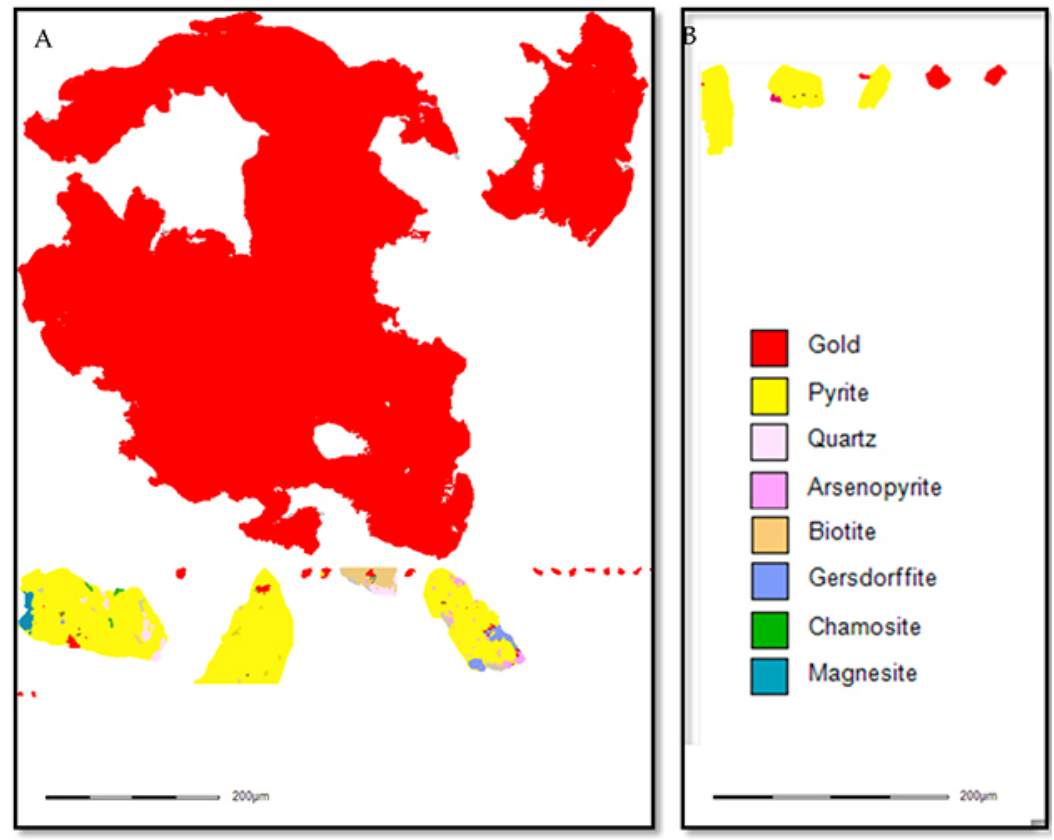

Figure 3-False colour image of gold grains generated from MLA data. (A) The Fairview sample shows a vast range in the sizes of gold grains associated with pyrite, where gold is represented in red. (B) The Barbrook gold is much finer-grained but is also associated with pyrite
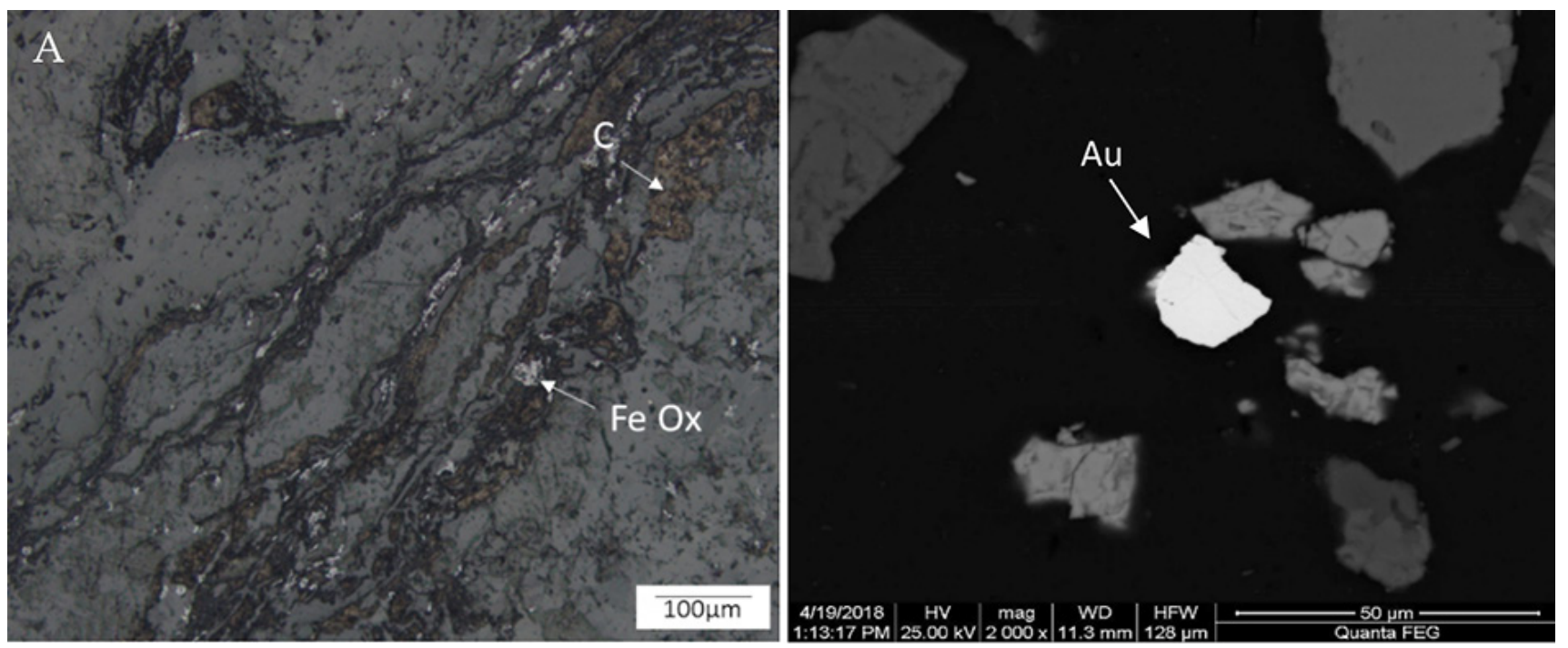

Figure 4-Barbrook samples. (A) The gold is too fine-grained to be visible in this reflected light image, but the associated deleterious occurrence of abundant iron oxide and particulate carbon is clear. (B) BSE image of one of the larger Barbrook gold grains found using the MLA (BSE image) with an ECD of 16.9 $\mu$ m

\section{Barbrook, Barberton}

The host lithology tends to be a highly altered carbonate-rich shale composed of quartz, dolomite, chlorite, muscovite, and carbon. Accessory iron-rich minerals range from highly abundant to entirely absent; secondary iron oxides such as limonite and goethite are also present (Figure 4A). Extensive veins are dominantly of carbonate and lesser quartz, with a range of orientations resulting in a stockwork texture. Ore minerals include pyrite, arsenopyrite, and minor chalcocite, galena, and pyrrhotite. Only a limited number of gold grains were identified using MLA (Figures 4B, 3B) and these ranged in size from $1 \mu \mathrm{m}$ to $20 \mu \mathrm{m}$. The gold tends to be associated only with pyrite $(10.0 \%)$, which is unlikely to significantly affect leaching conditions. A comparison of assayed (Table I) and mineralogically calculated gold grades suggests that $40 \%$ of the gold is present as solid solution in arsenopyrite, a feature also commented on by Anhaeusser (2001) and Pearton and Viljoen (2017).

\section{Consolidated Murchison}

The mineralization at Consolidated Murchison is hosted by altered schists, consisting predominantly of carbonate and quartz with lesser chlorite, biotite, and magnesite and locally abundant tourmaline. Ore minerals present include stibnite $\left(\mathrm{Sb}_{2} \mathrm{~S}_{3}\right)$, pyrite, berthierite $\left(\mathrm{FeSb}_{2} \mathrm{~S}_{4}\right)$, and lesser arsenopyrite (Figure 5A). Gold tends to be disseminated homogenously throughout the schist with grain sizes ranging from $2 \mu \mathrm{m}$ to $32 \mu \mathrm{m}$. Assays confirm a grade of $3 \mathrm{~g} / \mathrm{t}$ (Table I), and this low grade is reflected in the number of gold grains located and identified. The MLA results 


\section{Depositional environment - The original control on gold processing}
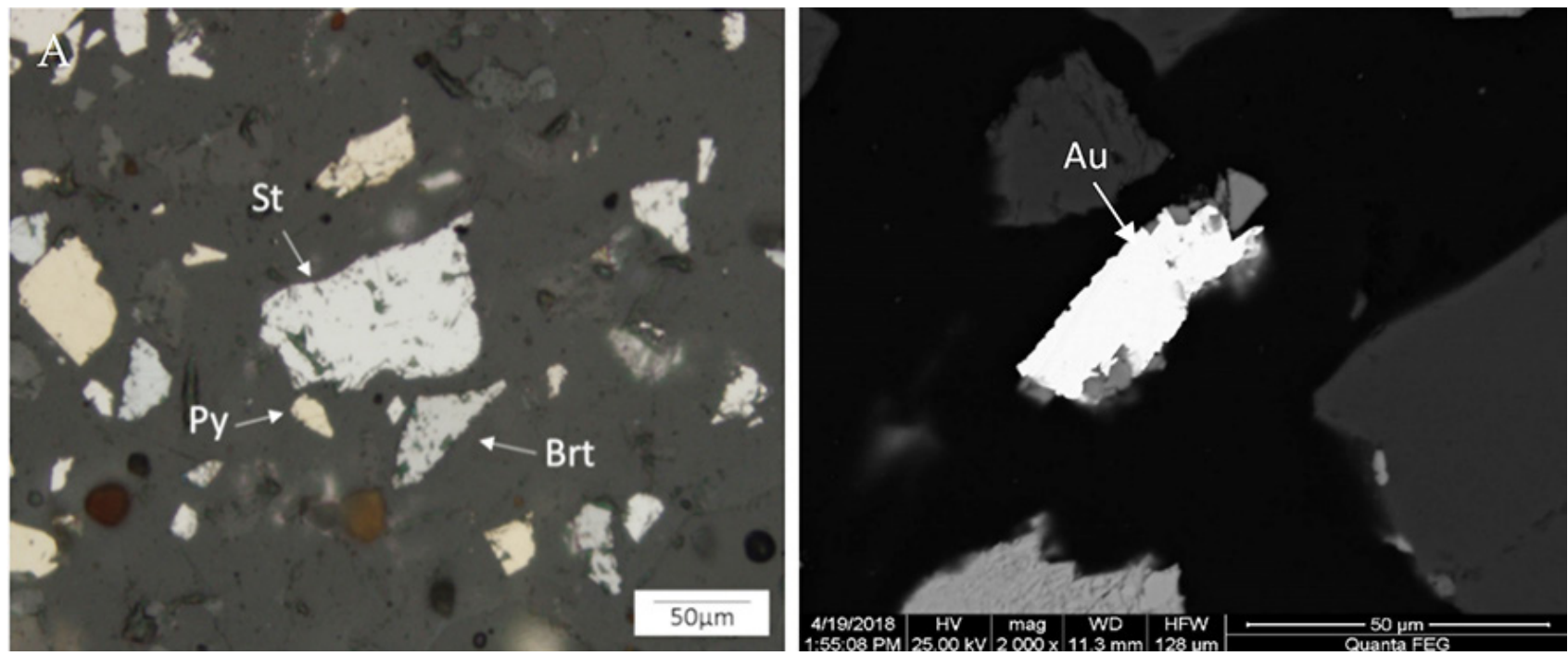

Figure 5-Ore minerals in Consolidated Murchison sample. (A) Shown in reflected light, stibnite (St), pyrite (Py,) and berthierite (Brt) in an altered shale matrix which appears as dull grey in reflected light. (B) The gold grain is well liberated and exposed, with an ECD of $25.5 \mu \mathrm{m}$
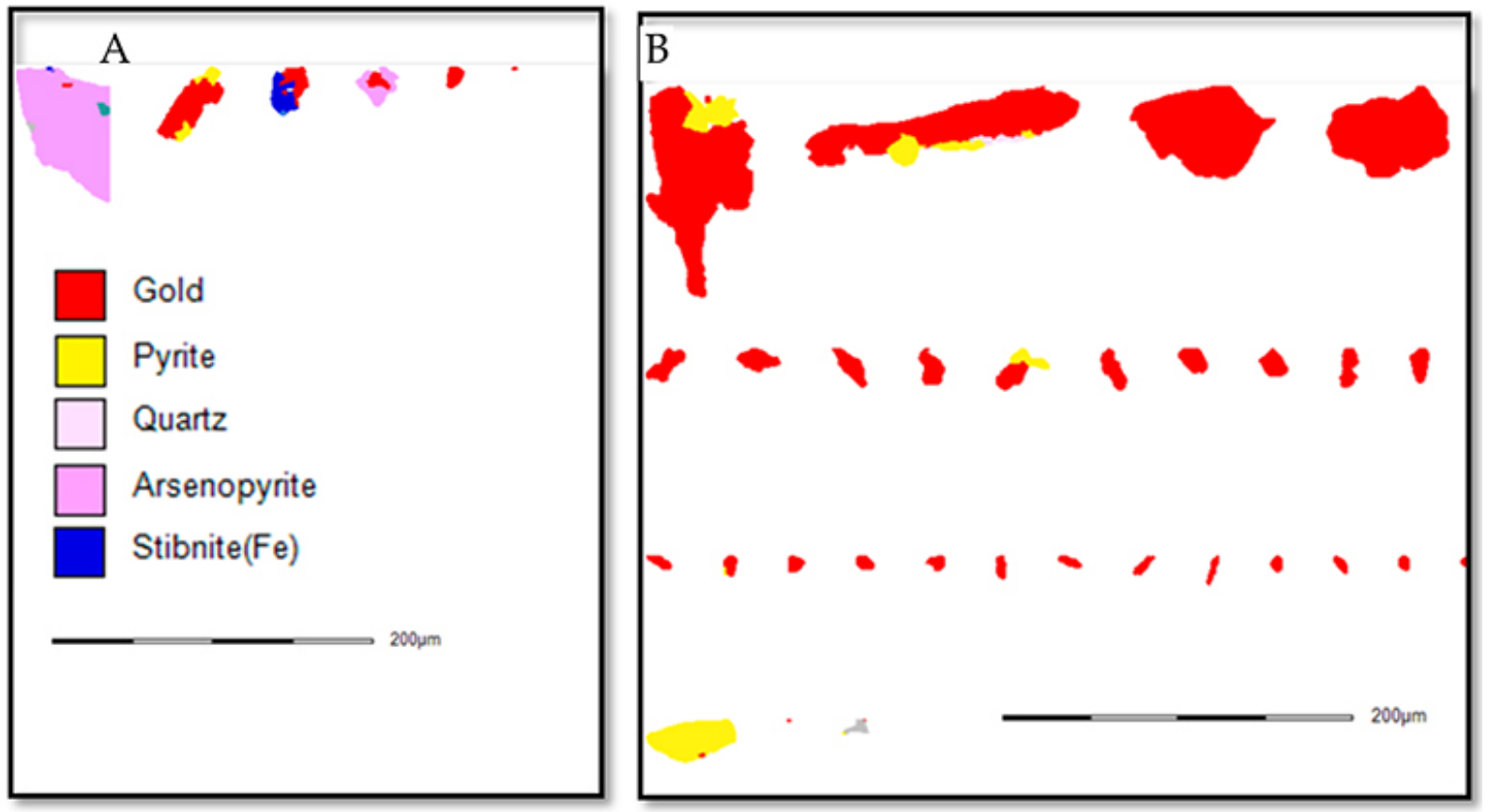

Figure 6-False colour image of gold grains generated from MLA data. (A) Consolidated Murchison gold grains, highlighting both the paucity of native gold grains and the low degree of liberation. (B) Gold grains derived from the Pilgrim's Rest sample, showing the range in grain size and the excellent liberation and exposure

suggest that the gold is less liberated (71.9\%) than in the other samples investigated (Figure 6A); however, $91.3 \%$ of the gold is available/exposed for leaching (Figure 5B). Accessory minerals include arsenopyrite $(15.7 \%)$, pyrite $(13.6 \%)$, and stibnite $(11.6 \%)$. The association of the gold and gold-bearing minerals with antimony-rich minerals such as stibnite will affect the leaching potential, due to both reagent consumption and passivation. The limited presence of native gold suggests that in addition to the coarse free grains and aurostibite, gold is also present in solid solution in arsenopyrite and aurostibite (Davis, 1986; Marsden and House, 2006; Vearncombe et al., 1988).

\section{Pilgrim's Rest}

The host lithology is predominantly a fine-grained shale composed of quartz and fine-grained micas, crosscut by quartzcarbonate veins ranging from millimetres to metres in width. Within the veins, sulphides occur both as disseminations and massive mineralization. Gold occurs as discrete, fine grains, ranging in size from $1.5 \mu \mathrm{m}$ to $75 \mu \mathrm{m}$ (Figure 6B). The sulphides are dominated by abundant pyrite, representing approximately one third, by mass, of the feed, with lesser pyrrhotite (Figure $7 \mathrm{~A})$, chalcocite, and chalcopyrite, together with the native gold (Figure 7B). Assay results show high concentrations of both gold $(29.4 \mathrm{~g} / \mathrm{t}$ ) and copper (7230 ppm) (Table I). While previous data suggests that a significant proportion of the gold in this ore is typically less than $5 \mu \mathrm{m}$ in size (Swiegers, 1948), the contribution of gold in this size range to the overall weight percentage was found to be insignificant. Rather more than 


\section{Depositional environment - The original control on gold processing}
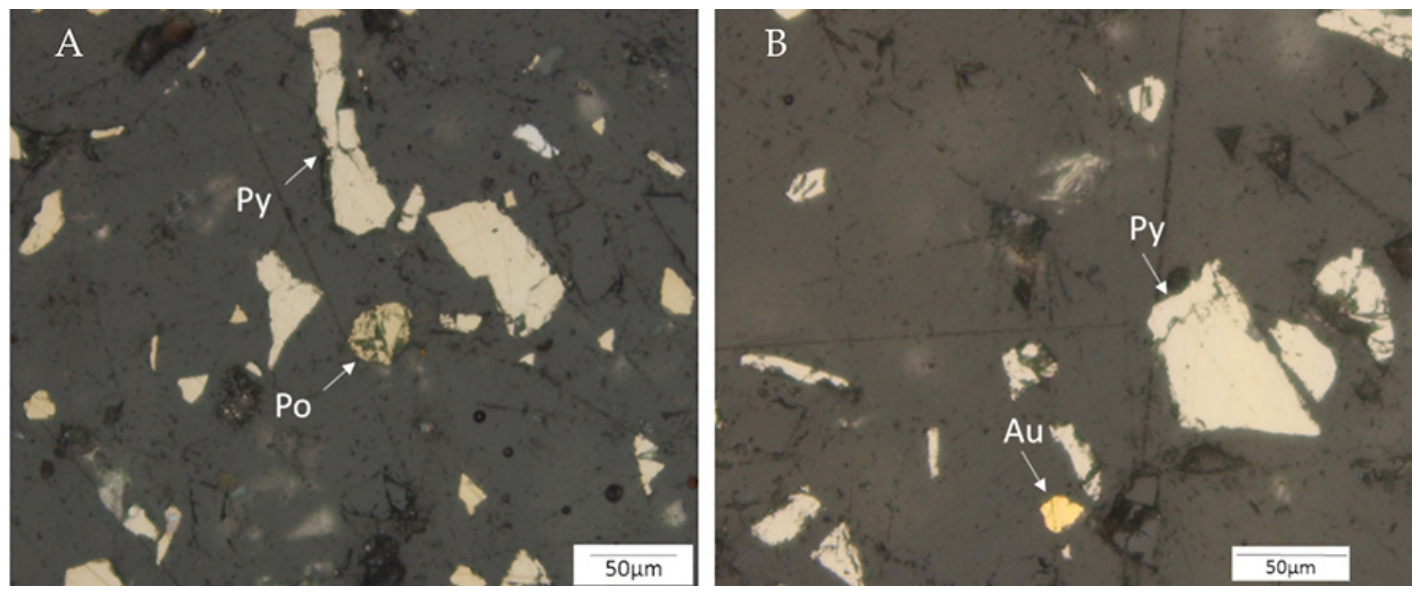

Figure 7-Pilrim's Rest material imaged in reflected light. (A) Typical field of view showing the abundant pyrite (py) and deleterious pyrrhotite (po). (B) A gold grain with an equivalent circular diameter of $16 \mu \mathrm{m}$, with significant accessory pyrite also evident

$85 \mathrm{wt} \%$ of the gold was in grains between $10 \mu \mathrm{m}$ and $75 \mu \mathrm{m}$ is size. Gold mineral associations include pyrite and quartz, which are unlikely to affect the gold extraction.

\section{Discussion}

Gold deposits occur in a number of different geological settings. Deposits such as those of Barberton are associated with shortterm tectonic extension following a period of mountain building (de Ronde, 1994; Dirks et al., 2013) while others formed from hydrothermal fluids associated with the intrusion of basaltic/ mafic magma, such as at Pilgrim's Rest (Boer et al., 1995). Other deposits are entirely hosted in sedimentary rocks, such as the Carlin type deposits in Nevada (Cline et al., 2005), while high-sulphidation epithermal gold deposits are formed at shallow crustal levels associated with volcanic activity. However, some deposit types are more likely to be refractory than others. Examples of deposits that are more likely to be free milling include placer and low-sulphidation epithermal systems (volcanic-related mineralization). Conversely, Carlin (disseminated, sedimentary-hosted), high-sulphidation epithermal and, important to this study, atypical greenstone deposits of disseminated stockwork type, tend to be refractory (Rowe, 2007).

In this study we have identified a number of factors that are likely to affect the successful extraction of gold from certain types of deposit, depending on both the gangue phases and the nature of the gold occurrence. The processing procedures for each deposit have been adapted to account for these factors.

The Fairview ore is refractory as the gold is sulphide-hosted. During processing the sulphides are destroyed using biological oxidation (BIOX) prior to leaching. No deleterious effects are encountered from the quartz, chlorite, or dolomite that comprise the dominant minerals of the host rock.

The Barbrook ore is refractory/complex due to the coexistence of sulphide-hosted gold and preg-robbing carbon. The ore therefore undergoes a series of flotation steps in order to concentrate the gold-bearing sulphides. The sulphide concentrate is subjected to ultrafine milling and pressure oxidation, which releases the gold and allows effective leaching. Cyanidation is then undertaken with the gold loading onto resin-in-leach in order to reduce preg-robbing effects (Grant, 2004). At a grind size of $80 \%$ of $-75 \mu \mathrm{m}$ the visible gold observed had excellent liberation and exposure, so any increased grinding would have a negligible positive impact on the gold recovery.

The Consolidated Murchison ore contains antimony which, during gold extraction, is thought to act as an oxygen scavenger (Monhemius, 1987), while increasing both cyanide and lime consumption. There is also evidence that the gold becomes passivated in the presence of antimony sulphides during normal cyanidation (Millard, 2005; Rohner and Millard, 2016). Gold extraction at Consolidated Murchison involves first separating out free gold using gravity concentration. The remaining ore is then subjected to flotation, concentrating both gold and stibnite. The gold is subsequently recovered from the flotation concentrate using a low-alkalinity, high-pressure (8.8 MPa) cyanidation process in a $1.5 \mathrm{~km}$ pressure pipe reactor (Davies and Paterson, 1986; Millard, 2005).

The Pilgrim's Rest ore shows no evidence of refractory gold. In addition, the excellent liberation and exposure would suggest that this ore is well disposed to cyanide leaching. However, significant copper concentrations $(0.7 \%)$ adversely affect leaching, as copper competes with gold to form cyanide complexes (Deschênes and Prud'homme, 1997). In addition, the Pilgrim's Rest ore has notable quantities of pyrrhotite, which can consume cyanide and reduced leaching kinetics (Dai and Jeffrey, 2006). Due to the complex mineralogical components of Pilgrim's Rest ore, flotation and roasting are employed prior to cyanidation.

The key mineralogical components identified as responsible for the refractory nature of the deposits of interest include solidsolution gold, preg-robbing carbon, and reactive minerals (Figure 8). Their origins can be better constrained by understanding the genesis of these deposits.

Large proportions of the gold at Fairview and Barbrook are present within the crystal lattice of arsenopyrite. Submicroscopic gold is thought to be incorporated into the crystal lattices during mineralization at sub- to lower greenschist facies conditions. As indicated in Figure 8, with an increase in metamorphic (PT) conditions, the gold is progressively ejected from the lattice, first into fractures and occlusions within the sulphides and finally into discrete minerals within the gangue (Vaughan and Kyin, 2004). However, most of the orogenic belts in South Africa have undergone only low-grade/greenschist metamorphism. Consequently, the gold has largely remained within the arsenopyrite, resulting in the refractory nature of 


\section{Depositional environment - The original control on gold processing}

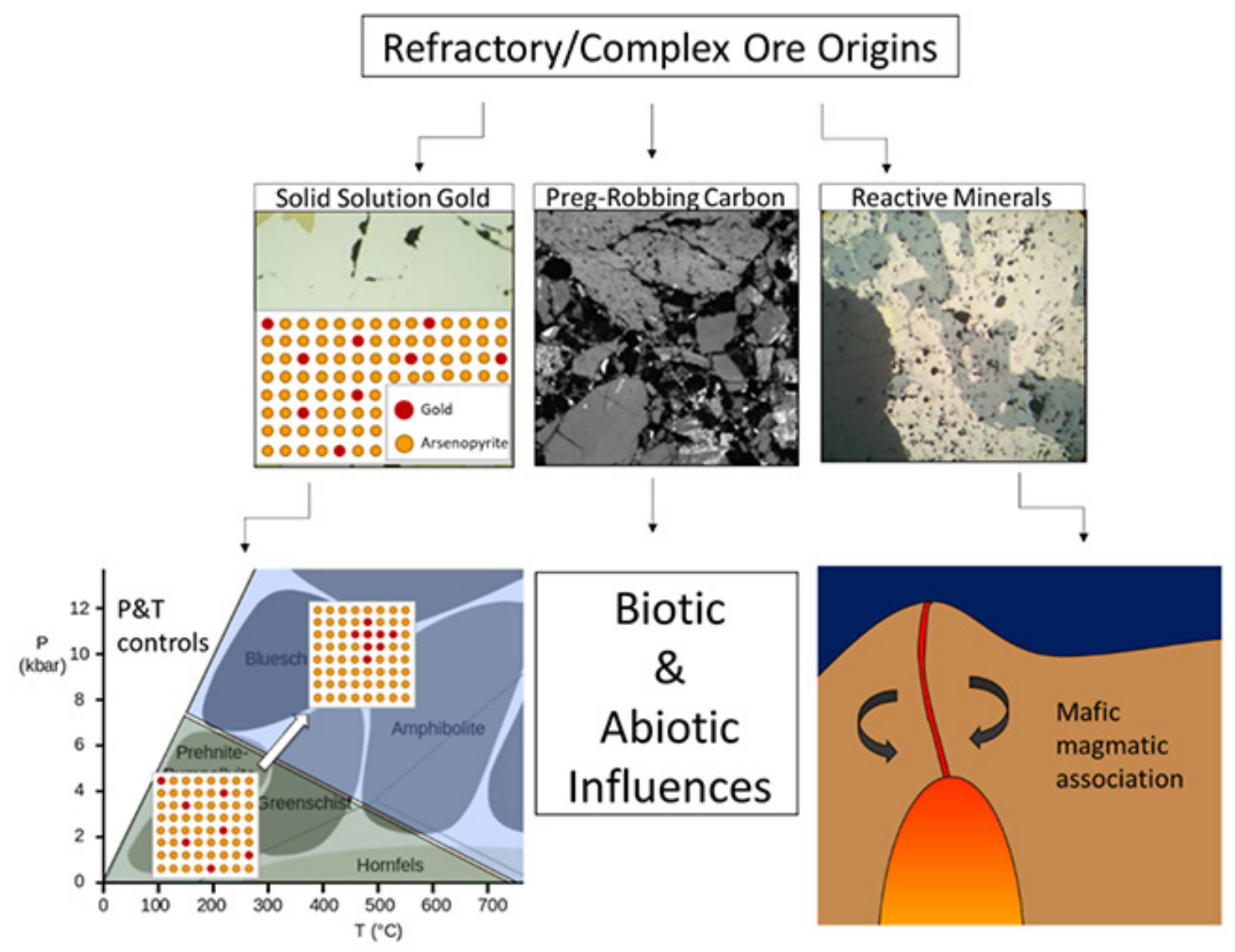

Figure 8-A schematic diagram showing the key components responsible for the refractory nature of gold deposits and some factors that influence this. Increasing metamorphic graded causes the gold in the arsenopyrite crystal lattice to be ejected, while both biotic and abiotic factors are responsible for the formation and perseveration of preg-robbing carbon. A deposit associated with mafic magmatic fluids would likely contain reactive pyrrhotite

orogenic gold deposits that are characterized by low-temperature metamorphism (Foster and Piper, 1993). Other orogenic lode gold deposits that have undergone only low-grade metamorphism can also be expected to be refractory. This means that mineralogical assessments of potential deposits in these regions should be prioritized, in order to determine gold occurrence and prevent unexpected processing complications.

Arsenic tends to be enriched within sedimentary, rather than igneous, lithologies. The arsenic concentration in metamorphic units is strongly dependant on the original protolith, and arsenic is not significantly enriched during metamorphism (Tanaka, 1988). Arsenic enrichment in sedimentary material is thought to take place during the sedimentation process, with finer grained sediments typically having higher As concentrations (Tanaka, 1988). Thus gold-bearing provinces hosted in fine-grained sedimentary lithologies are more likely to be enriched in arsenic than other gold deposit types, and assays performed on this type of ore should include arsenic.

Antimony is another element with deleterious effects, typified by the Consolidated Murchison ore in this study. The mechanisms that constrain antimony concentration globally are not well understood, although a series of analyses on samples from various lithologies and localities indicated that antimony enrichment occurs in sediments (notably shales and argillites), as well as andesites and rhyolites (Boyle and Jonasson, 1984). The original rock types at Consolidated Murchison were a mix of volcanic and sedimentary units that later underwent metamorphism. The metasedimentary nature of the sample studied accounts for the arsenic enrichment. While these conditions of formation may not be well constrained, the inclusion of antimony in early assays for prospects with relevant lithologies (shales, argillites, andesites, and rhyolites) would be a simple and cheap method of identifying potential processing complications relating to antimony.

Potentially preg-robbing carbonaceous components may originate from both biotic and abiotic factors (Welte, 1969). Examples of factors that control the formation and preservation of preg-robbers include initial presence and oxygen availability (both of which may vary on a scale of metres), iron concentration, burial rate, and subsequent metamorphism (Meyers, 2007; Pedersen and Calvert, 1990; Welte, 1969). The variability of factors is emphasized by the contrasting examples of Fairview and Barbrook. While these economic gold deposits formed in the same vicinity, at the same time, from the same mineralizing events and in the same stratigraphic units, they have distinctly different carbonaceous natures. For this reason the occurrence of preg-robbing carbon cannot be readily constrained based on the conditions of deposit formation and as such would need to be evaluated for each deposit of interest. Fortunately, there are highly effective methods of addressing the occurrence of preg-robbing carbon during processing.

Pyrrhotite, one of the most common base metal minerals in complex gold ores, can increase cyanide consumption and reduce leaching kinetics. Primary pyrrhotite forms predominantly in mafic to ultramafic intrusions, which do not typically host primary gold deposits. However, hydrothermal fluids from these 


\section{Depositional environment - The original control on gold processing}

intrusions are also commonly responsible for pyrrhotite formation (Gordon and McDonald, 2015; Vaughn, 1982). Hydrothermal deposits are the most widespread type on Earth and the hydrothermal fluids from which pyrrhotite precipitated are often a mix of magmatic, metamorphic, or diagenetic fluids (Reed and Palandri, 2006). However, where the hydrothermal fluids can be linked to an original mafic magmatic source, as typified by Pilgrim's Rest (Figure 8), it is a good indication of the potential for processing complexities.

\section{Conclusion}

Several mineralogical features of gold ores can cause processing complications. The study of four complex/refractory deposits in South Africa highlighted several of these features: gold locked within arsenopyrite, preg-robbing carbon, reactive minerals such as pyrrhotite, and antimony-bearing phases. From this study it is possible to determine what features of deposit formation were responsible for these complicating mineralogical components. Solid-solution gold is linked to mineralization in regions that have experienced only low pressure and temperature conditions and are hosted in fine-grained sedimentary units. Reactive pyrrhotite will be present in gold deposits associated with hydrothermal fluids emanating from mafic magmatism.

Desktop studies and remote targeting are increasingly important steps in gold exploration, and the conditions in which complex deposits form could be readily incorporated into this approach, which could enable the selective targeting of freemilling/readily extractable deposits, reducing complications and expenses throughout the gold recovery process. Should it not prove possible to avoid these complex deposits entirely, these conditions of formation may act as a warning system to allow for mineralogical and metallurgical considerations early in the project pipeline.

\section{Acknowledgments}

The support of the DST-NRF Centre of Excellence for Integrated Mineral and Energy Resource Analysis (DSI-NRF CIMERA) towards this research is hereby acknowledged. Opinions expressed and conclusions arrived at are those of the authors and are not necessarily to be attributed to the CoE. The authors would also like to express their gratitude to Bradley Guy for his invaluable technical assistance.

\section{References}

AnHAeusser, C.R. 2015. The stratigraphy, structure, and gold mineralization of the Jamestown and Sheba Hills areas of the Barberton Mountain Land. PhD thesis, University of the Witwatersrand, Johannesburg.

AnHaeusser, C.R. 2001. Barberton Greenstone Belt. Economic Geology Research Unit, University of the Witwatersrand.

AyLmore, M.G. and Muir, D.M. 2001. Thiosulfate leaching of gold-a review: Minerals Engineering, vol. 14. pp. 135-174.

Barker, S.L., Hickey, K.A., Cline, J.S., Dipple, G.M., Kilburn, M.R., Vaughan, J.R., and Longo, A.A. 2009. Uncloaking invisible gold: Use of nanoSIMS to evaluate gold, trace elements, and sulfur isotopes in pyrite from Carlin-type gold deposits: Economic Geology, vol. 104. pp. 897-904.

Batн, E.R. and Duncan, A.J. 1973. Some factors influencing gold recovery by gravity concentration. Journal of the South African Institute of Mining and Metallurgy, vol. 73, no. 11. pp. 363-384.

Boer, R., Meyer, F., Robb, L., Graney, J., Vennemann, T., and Kesler, S. 1995.
Mesothermal-type mineralization in the Sabie-Pilgrim's Rest gold field, South Africa. Economic Geology, vol. 90. pp. 860-876.

Boyle, R. and JonAsson, I. 1984. The geochemistry of antimony and its use as an indicator element in geochemical prospecting. Journal of Geochemical Exploration, vol. 20. pp. 223-302.

BURT, R. 1999. The role of gravity concentration in modern processing plants. Minerals Engineering, vol. 12, no. 11. pp. 1291-1300.

Chryssoulis, S. and McMulLen, J. 2005. Mineralogical investigation of gold ores. Developments in Mineral Processing, vol. 15. pp. 21-71.

Chryssoulis, S.L., CABri, L.J., and SAlter, R.S. 1987. Direct determination of invisible gold in refractory sulphide ores. Proceedings of the Metallurgical Society of the Canadian Institute of Mining and Metallurgy. Pergamon, Oxford. pp. 235-244.

Cline, J.S., Hofstra, A.H., Muntean, J.L., Tosdal, R.M. and Hickey, K.A. 2005. Carlintype gold deposits in Nevada: Critical geologic characteristics and viable models. Economic Geology 100th Anniversary Volume. pp. 451-484. doi:10.5382/ av100.15

Congress, C.M.a.M. 1961. Notes dealing with the geology, mineralogy, mining, metallurgy and history of Pilgrims Rest, with particular reference to the Transvaal Gold Mining Estates, Limited. Presented to the 7th Commonwealth Mining and Metallurgical Congress, April 1961. Historical Papers Research Archive, University of the Witwatersrand. Ref. A1270f. 8 pp. Mimeog.

DAI, X., Breuer, P., and JefrRey, M. 2010. Comparison of activated carbon and ion-exchange resins in recovering copper from cyanide leach solutions. Hydrometallurgy, vol. 101. pp. 48-57.

DAI, X. and JEFFrey, M.I. 2006. The effect of sulfide minerals on the leaching of gold in aerated cyanide solutions. Hydrometallurgy, vol. 82. pp. 118-125.

DAviEs, D.R. and PATERSon, D.B. 1986. Practical implementation of low alkalinity pressure cyanidation leaching techniques for the recovery of gold from refractory flotation concentrates. Gold 100. Proceedings of the International Conference on Gold: Vol. 2. Wagner, H. (ed.). South African Institute of Mining and Metallurgy, Johannesburg. pp. 591-604.

DAvIs, D. 1986. Antimony in South Africa. Journal of the South African Institute of Mining and Metallurgy, vol. 86. pp. 173-193.

De Ronde, C.E., DE Wit, M.J., and Spooner, E.T. 1994. Early Archean (> 3.2 Ga) Feoxide-rich, hydrothermal discharge vents in the Barberton greenstone belt, South Africa: Geological Society of America Bulletin, vol. 106. pp. 86-104.

Deschênes, G. and Prud'Homme, P. 1997. Cyanidation of a copper-gold ore. International Journal of Mineral Processing, vol. 50. pp. 127-141.

Dirks, P., Charlesworth, E., and Munyai, M. 2009. Cratonic extension and Archaean gold mineralisation in the Sheba-Fairview mine, Barberton Greenstone Belt, South Africa. South African Journal of Geology, vol. 112. pp. 291-316.

Dirks, P.H., Charlesworth, E.G., Munyai, M.R., and Wormald, R. 2013. Stress analysis, post-orogenic extension and $3.01 \mathrm{Ga}$ gold mineralisation in the Barberton Greenstone Belt, South Africa. Precambrian Research, vol. 226. pp. 157-184.

EIDEM, I. and L. Lundevall. 1974. Chlorine - Glimpses from its history. Proceedings of the Chlorine Bicentennial Symposium. The Electrochemical Society, Princeton, NJ.

Fivaz, C.E. 1988. Presidential Address: How the MacArthur-Forrest cyanidation process ensured South Africa's golden future. Journal of the South African Institute of Mining and Metallurgy, vol. 88, no. 9. pp. 309-318.

Foster, R. and Piper, D. 1993. Archaean lode gold deposits in Africa: Crustal setting, metallogenesis and cratonization. Ore Geology Reviews, vol. 8. pp. 303-347.

Fraser, K., Walton, R., and Wells, J. 1991. Processing of refractory gold ores. Minerals Engineering, vol. 4. pp. 1029-1041.

Goldfarb, R., Groves, D., and Gardoll, S. 2001. Orogenic gold and geologic time: A global synthesis. Ore Geology Reviews, vol. 18. pp. 1-75.

Goodall, W.R., LEATHAM, J.D., and Scales, P.J. 2005. A new method for determination of preg-robbing in gold ores. Minerals Engineering, vol. 18. pp. 1135-1141. 


\section{Depositional environment - The original control on gold processing}

Gordon, S.C. and McDonald, A.M. 2015. A study of the composition, distribution, and genesis of pyrrhotite in the Copper Cliff offset, Sudbury, Ontario, Canada. Canadian Mineralogist, vol. 53. pp. 859-878.

Grant, D. 2004. Barbrook Mines Limited, Mpumalanga Province, South Africa. Independent Qualified Person's Report. https://www.caledoniamining.com/wpcontent/uploads/2019/02/barbTechFull.pdf

Groves, D.I., Goldfarb, R.J., Gebre-Mariam, M., Hagemann, S., and Robert, F. 1998. Orogenic gold deposits: a proposed classification in the context of their crustal distribution and relationship to other gold deposit types. Ore Geology Reviews, vol. 13. pp. 7-27.

HABASHI, F. 1967. Kinetics and mechanism of gold and silver dissolution in cyanide solution. Geological Bulletin, no. 59. Montana Bureau of Mines. 42 pp.

HAQUE, K. 1987. Gold leaching from refractory ores-Literature survey. Mineral Procesing and Extractive Metallurgy Review, vol. 2. pp. 235-253.

HARRIS, D. 1990, The mineralogy of gold and its relevance to gold recoveries. Mineralium Deposita, vol. 25. pp. S3-S7.

HASAB, M.G., RASHCHI, F., and RaYGAN, S. 2014. Chloride-hypochlorite leaching and hydrochloric acid washing in multi-stages for extraction of gold from a refractory concentrate. Hydrometallurgy, vol. 142. pp. 56-59.

Jaguin, J., Poujol, M., Boulvais, P., RobB, L., and Paquette, J.-L. 2012. Metallogeny of precious and base metal mineralization in the Murchison Greenstone Belt, South Africa: Indications from $\mathrm{U}-\mathrm{Pb}$ and $\mathrm{Pb}-\mathrm{Pb}$ geochronology. Mineralium Deposita, vol. 47. pp. 739-747.

JANISCH, P.R. 1986. Gold in South Africa. Journal of the South African Institute of Mining and Metallurgy, vol. 86. pp. 273-316.

Karimi, P., Abdollahi, H., Amini, A., Noaparast, M., Shafaei, S., and Habashi, F. 2010. Cyanidation of gold ores containing copper, silver, lead, arsenic and antimony. International Journal of Mineral Processing, vol. 95. pp. 68-77.

Kissin, S. and Scotr, S. 1982. Phase relations involving pyrrhotite below 350 degrees C. Economic Geology, vol. 77. pp. 1739-1754.

Komnitsas, C. and Pooley, F.D. 1989. Mineralogical characteristics and treatment of refractory gold ores. Minerals Engineering, vol. 2. pp. 449-457.

Kongolo, K. and Mwema, M. 1998. The extractive metallurgy of gold. Hyperfine Interactions, vol. 111. pp. 281-289.

LA Brooy, S., Linge, H., and WALKER, G. 1994. Review of gold extraction from ores. Minerals Engineering, vol. 7. pp. 1213-1241.

Lindström, E.B., GunNeriusson, E., and Tuovinen, O.H. 1992. Bacterial oxidation of refractory sulfide ores for gold recovery. Critical Reviews in Biotechnology, vol. 12. pp. 133-155.

Marsden, J. and House, I. 2006. The Chemistry of Gold Extraction. Ellis Horwood, Chichester.

McNulty, T. 1989. A metallurgical history of gold. Proceedings of the American Mining Congress, San Francisco, September 1989.

Meyer, F. and Roвb, L. 1996. The geochemistry of black shales from the Chuniespoort Group, Transvaal sequence, eastern Transvaal, South Africa. Economic Geology, vol. 91. pp. 111-121.

MEYERS, S.R. 2007. Production and preservation of organic matter: The significance of iron. Paleoceanography, vol. 22, no. 4. https://doi. org/10.1029/2006PA001332

MilLaRd, M. 2005. Treatment of antimonial gold ores. Developments in Mineral Processing, vol. 15. pp. 985-991.

Miller, J., WAN, R.-Y., and Diaz, X. 2005. Preg-robbing gold ores. Developments in Mineral Processing, vol. 15. pp. 937-972.

Moffa, J. 1977. Physical and mechanical properties of gold and base metal alloys. Proceedings of Alternatives to Gold Alloys in Dentistry. Valega, T.M. (ed.). US
Department of Health, Education, and Welfare, Public Health Service, National Institutes of Health.

Monhemius, A. 1987. Recent advances in the treatment of refractory gold ores. Proceedings of the II Meeting of the Southern Hemisphere on Mineral Technology, Rio de Janeiro. http://www.imperial.ac.uk/respub/ MONHEMIUS-1987-644335.ris

Munyai, M., Dirks, P., and Charlesworth, E. 2011. Archaean gold mineralisation during post-orogenic extension in the new consort gold mine, Barberton Greenstone Belt, South Africa. South African Journal of Geology, vol. 114. pp. 121-144.

Pearton, T. 1982. Gold and antimony mineralization in altered komatiites of the Murchison greenstone belt, South Africa. Komatiites. George Allen and Unwin, London. pp. 459-475.

Pearton, T. and Viljoen, M. 2017. Gold on the Kaapvaal Craton, outside the Witwatersrand Basin, South Africa. South African Journal of Geology, vol. 120. pp. 101-132.

Pedersen, T. and Calvert, S. 1990. Anoxia vs. productivity: What controls the formation of organic-carbon-rich sediments and sedimentary rocks? AAPG Bulletin, vol. 74. pp. 454-466.

REARDon, A.C. 2011. Metallurgy for the Non-metallurgist. ASM International, Materials Park, $\mathrm{OH}$.

Reed, M.H. and Palandri, J. 2006. Sulfide mineral precipitation from hydrothermal fluids. Reviews in Mineralogy and Geochemistry, vol. 61. pp. 609-631.

Rohner, P. and Millard, M. 2016. Treatment of antimonial gold ores. Gold Ore Processing. 2nd edn. Elsevier. pp. 927-933.

Rowe, R. and Zно, X. 2007. Models and exploration methods for major gold deposit types. Proceedings of Exploration, vol. 7. p. 691-711.

Stanley, G.G. 1987. The Extractive Metallurgy of Gold in South Africa. vol. 7. South African Institute of Mining and Metallurgy, Johannesburg.

Swiegers, J. 1948. The gold deposits of the Pilgrims Rest gold mining district, Transvaal. South African Journal of Geology, vol. 51. pp. 81-132.

Tanaka, T. 1988. Distribution of arsenic in the natural environment with emphasis on rocks and soils. Applied Organometallic Chemistry, vol. 2. pp. 283-295.

TyLER, N. 1986. The origin of gold mineralization in the Pilgrim's Rest Goldfield, Eastern Transvaal. Information Circular no. 179. Economic Geology Research Unit, University of the Witwatersrand.

Tyler, R. and Tyler, N. 1996. Stratigraphic and structural controls on gold mineralization in the Pilgrim's Rest goldfield, eastern Transvaal, South Africa. Precambrian Research, vol. 79. pp. 141-169.

VAughan, J. 2004. The process mineralogy of gold: The classification of ore types JOM, vol. 56. pp. 46

VAughan, J. and Kyin, A. 2004. Refractory gold ores in Archaean greenstones, Western Australia: Mineralogy, gold paragenesis, metallurgical characterization and classification. Mineralogical Magazine, vol. 68. pp. 255-277.

VAughn, J.C.D. 1982. Phase relations involving pyrrhotite below 350 degrees C. Economic Geology, vol. 77. pp. 1739-1754.

Vearncombe, J., Cheshire, P., de Beer, J., Killick, A., Mallinson, W., McCourt, S., and StetTler, E. 1988. Structures related to the Antimony Line, Murchison schist belt, Kaapvaal Craton, South Africa. Tectonophysics, vol. 154. pp. 285-308.

WARD, J. 1999. The metallogeny of the Barberton greenstone belt, South Africa and Swaziland. Council for Geoscience, Pretoria, South Africa.

Welte, D. 1969. Organic matter in sediments. Organic Geochemistry. Eglinton, G. and Murphy, M.T.J. (eds). Springer. pp. 262-264.

Zноu, J.Y. and CABRi, L.J. 2004. Gold process mineralogy: Objectives, techniques, and applications. JOM, vol. 56. pp. 49-52. 